\title{
A bizalom és az empatikus kommunikáció szerepe és eszközei az egészségügyben a COVID-19-járvány idején
}

\author{
Gács Boróka dr. ${ }^{1}$. Kovács Petra ${ }^{2}$ - Birkás Béla dr. ${ }^{1}$ - Füzesi Zsuzsanna dr. ${ }^{1}$ \\ ${ }^{1}$ Pécsi Tudományegyetem, Általános Orvostudományi Kar, Magatartástudományi Intézet, Pécs \\ ${ }^{2}$ Országos Mentőszolgálat, Pszichológiai és Mentálhigiénés Csoport, Budapest
}

\begin{abstract}
A járvánnyal szembeni védekezés során mindennapossá vált a maszkhasználat, amely jelentős kihívást jelent a hétköznapi kommunikációs helyzetekben. Az egészségügy bizonyos területein korábban is jelen volt ez a probléma, azonban a most általános érvényú, folyamatos maszkviselés és védőruha-használat szimbolikus és gyakorlati értelemben is akadályként jelenik meg az orvos és a páciens között, ami több szinten nehezíti a hatékony kapcsolatteremtést és kommunikációt. Ezért szükségessé vált olyan egységes kommunikációs protokollok kidolgozása, amelyek segítik a bizalmi kapcsolat kiépítését az egészségügyben úgy, hogy az ellátók érzelmi elérhetôsége és a biztonságos fizikai távolságtartás egyszerre valósuljon meg. Tanulmányunk célja, hogy a kurrens szakirodalom áttekintése révén összefoglaljuk a maszkviselés és a védőruha-használat hatásait az orvos-beteg kommunikációra és a kapcsolatban megjelenő bizalomra és empátiás folyamatokra, valamint fel kívánjuk hívni a figyelmet az egészségügyi személyzetet érő hatásokra is. Célunk továbbá, hogy a hazai és nemzetközi tapasztalatokat figyelembe véve olyan ajánlásokat fogalmazzunk meg, melyek segítségével javítható az egészségügyi dolgozók kommunikációja, azon keresztül pedig az ellátás legfontosabb szereplőinek, a betegeknek és az ellátóknak az elégedettsége a kapcsolattal.
\end{abstract}

Orv Hetil. 2021; 162(23): 897-904.

Kulcsszavak: maszk, kommunikáció, empátia, bizalom

\section{The role and tools of trust and empathic communication in healthcare during the COVID-19 epidemic}

In the fight against the epidemic, the use of masks has become commonplace, which is a significant challenge in everyday communication situations. This problem has been present in some areas of healthcare in the past, but today's universal use of masks and personal protective equipment (PPE) is both a symbolic and practical barrier between doctor and patient, making it difficult to establish an effective communication and connectivity on several levels. Therefore, it has become necessary to develop unified communication protocols that help building a relationship of trust in healthcare so that emotional availability of providers and safe physical distance are achieved simultaneously. The aim of our study is to summarize the effects of mask wearing and PPE usage on the physician-patient communication and also the trust and empathy processes that emerge within the relationship through the review of the current literature. We would also like to draw attention to the effects on healthcare staff. Our goal is also to formulate recommendations, taking into account domestic and international experience, that can be used to improve the communication of healthcare professionals, and through that, the satisfaction of the most important actors in care, patients and caregivers.

Keywords: masks, communication, empathy, trust

Gács B, Kovács P, Birkás B, Füzesi Zs. [The role and tools of trust and empathic communication in healthcare during the COVID-19 epidemic]. Orv Hetil. 2021; 162(23): 897-904.

(Beérkezett: 2021. március 1.; elfogadva: 2021. március 31.) 


\section{Rövidítés}

COVID-19 = (coronavirus disease 2019) koronavírus-betegség 2019; $\mathrm{HlNl}=$ a hemagglutinin 1 -es és a neuraminidáz l-es típusát tartalmazó vírus

A bizalom, az érzelmi biztonság, a páciensre fordított figyelem és empátia az alapja az ellátó/orvos és beteg közötti együttmúködésnek, amely hozzájárul az ellátás hatékonyságához, a beteg gyógyulásához és az egészségügyi dolgozók elégedettségéhez is [1]. Az együttérzést kifejező orvos nemcsak optimizmust és pozitív érzéseket vált ki pácienséból, de viselkedésének olyan élettani hatásai is vannak, amelyek a paraszimpatikus múködés fokozásával csökkentik a beteg szorongását. A betegek által észlelt empátia nagy valószínúséggel növeli elégedettségüket, és így közvetetten az orvos-beteg kapcsolatban kialakuló bizalom és együttmúködés mértékét is [2]. A betegekre viszont - kiszolgáltatottságuknál és fizikai állapotuknál fogva - megváltozott mentális állapot jellemző. A csökkent realitáskontroll következtében saját állapotukat kognitív torzításokon keresztül látják, a kommunikációs helyzetekben mindent önmagukra vonatkoztatnak, mindezt fokozottan negatív értelmezési kerettel [3]. Ezek a tényezők önmagukban is számos félreértést idézhetnek elő az ellátás során, a járványhoz, a fertőzéshez és a betegséghez kapcsolódóan azonban további téves vélekedésekkel, sztereotípiákkal és kognitív torzításokkal kell számolni a betegek részéről. Tanulmányok felhívják a figyelmet arra, hogy a COVID-19-betegek több szorongást és félelmet élnek át, ezért az egészségügyi ellátórendszerben az ellátók részéról az érzelmek kifejezésében és megértésében a tudatosság, a rugalmasság és az érzékenység magasabb szintjét igénylik [4].

A munkahelyi kommunikációval kapcsolatos igények és jellemzők változásai nemcsak a betegek, de az egészségügyi dolgozók esetében is tetten érhetők. Nemzetközi kutatások eredményei alapján a pandémia ideje alatt az egészségügyi dolgozók kevésbé kielégítő kommunikációról, a kommunikációs helyzetekben tapasztalható transzparencia csökkenéséról vagy hiányáról, a betegek részéről tapasztalt téves vélekedésekről és a biztonságérzet elvesztésétól való félelemről számoltak be [5]. Ezek alapján az egészségügyi dolgozók akár 20-90\%-át jelentősen zavarhatja a kommunikációban a maszk használata, ami csökkenti a maszkhasználatra vonatkozó adherenciát is [6-9]. Az egészségügyi dolgozók jó kommunikációs készsége összefügg azzal, hogy mennyire elégedettek a munkájukkal, ami pedig a kiégés ellen az egyik legfontosabb védőfaktor. Az empatikusabb gyógyítók érzelmileg nyitottabbak, jobban rá tudnak hangolódni a beteg igényeire, több sikerélményt élnek meg a gyógyításban, elkötelezettebbek, személyes elhivatottságuk nő, és kimerülés helyett ebből töltekezni tudnak [3]. A leginkább kognitív empátiaként határozhatjuk meg azt a szintet, melyben a hangsúly az empátiás pontosságon van, tehát annak a tudásán, hogy az adott helyzetben a másik mit érez. Ebben a megközelítésben az empátia létrejöttéhez nincs szükség arra, hogy a megfigyeló érzelmileg involválódjon. Az empátia affektív komponensén viszont az empátia emocionális aspektusát értjük, vagyis azt, hogy a megfigyelőben megjelenő érzések mennyire azonosíthatók a megfigyelt megélt érzéseivel. A kurrens kutatások alapján azonban a kognitív empátia önmagában nem elégséges a páciens érzelmi állapotának felismeréséhez, mivel ha az orvos, bár megfelelő kérdéseket tesz fel, de hiányoznak azok a - sok esetben nonverbális - jelek, melyek az érzelmi ráhangolódást jelzik, a páciens sokkal kevesebbet oszt meg legaggasztóbb tüneteiról. Abban az esetben viszont, ha a megfelelő kérdezéstechnika kiegészül az érzelmi hangolódás nonverbális jegyeivel, a páciens adherenciája is kedvezőbb, sőt ez a reflektált érzelmi bevonódás védőfaktor lehet az orvosi kiégés ellen [2]. Az egészségügyi dolgozók részéről kiemelt fontosságú az olyan hatékony kommunikációs stratégiák alkalmazása, melyek kompenzálják a maszkviselés és védőruha-használat miatt kieső, az empatikus kommunikáció indikátoraiként szolgáló verbális és nonverbális információkat. Ez az ellátók érdeke is, hiszen a kommunikáció javításával növelhetik énhatékonyságukat, amely szintén védelmet jelent a kiégéssel szemben [1].

A maszkviselés célja a páciensek és az egészségügyi dolgozók védelme a fertőzéstől, így a maszk sok esetben a biztonsággal, védelemmel asszociálódik. Ugyanis bármilyen, arcot takaró védőruházat viselésének pszichológiai, szimbolikus funkciója is van: ellensúlyozza a láthatatlan, globálisan fenyegető veszély okozta szorongást [10]. Ambivalens módon azonban negatív szuggesztióként, azaz olyan, önkéntelenül ható üzenetként is müködhet, amely negatív hatással van a páciens észlelésére. Ebben az esetben a fenyegetettség és veszteség érzése társulhat hozzá $[11,12]$. A negatív szuggesztió erôsíti a félelmet, növeli a bizalmatlanságot, rontja a gyógyulásba vetett hitet [13]. Korábbi kutatásokban kimutatták, hogy a maszk elsősorban akkor okoz fokozott szorongást, és válik negatív szuggesztiós kommunikációs elemmé, amikor a páciensnek már a kezelés kezdete előtt erősebb a szorongása és a félelemérzete, illetve amikor a maszk szorongást kiváltó hatását anticipálja [14]. Továbbá Wong és mtsai [15] úgy találták, hogy a maszk negatív hatása azokban az esetekben kifejezettebb, amikor azt megelőzi egy erősebb bizalomra és megalapozottabb kapcsolatra épülő orvos-beteg viszony. Vagyis a maszk elidegenítő hatása hangsúlyosabb, ha azt nem egy idegen viseli [15].

\section{A maszk és védőruházat okozta általános kommunikációs kihívások}

A kommunikáció verbális, vokális és nonverbális tényezőkből tevődik össze. Mindezekből a nonverbális jelzések bírnak a legnagyobb jelentőséggel, ugyanis becslések szerint a kommunikáció akár 60-80\%-a nonverbálisan történik [16-18]. A nonverbális jelek közé tartozik a 
szemkontaktus, a kommunikáció nyugtázása bólogatással, az érintés és az arckifejezések, például a mosoly. Éppen ez az a kommunikációs csatorna, amely a maszk és a védőruházat viselésének hatására jelentősen háttérbe szorul: a páciens nem látja kezelője arcát, mimikáját, a száj mozgását, így elveszik a taktilis információ, ami fokozhatja szorongását, kiszolgáltatottságérzését, és hátráltatja az információk feldolgozását [19]. Ezt alátámasztva több kutatásban is megállapították, hogy amikor az orvosok vagy gyógyszerészek maszkot viseltek, a betegek kevésbé észlelték őket empatikusnak és megbízhatónak $[15,20]$. Ez általánosságban is igaz: amikor egy maszkot viselő embert látunk, kevésbé érezzük érzelmileg közel magunkhoz [21]. Társadalmi-idegtudományi kutatások azt is bizonyították, hogy az eltakart arc torzítja az érzelemfelismerést a fogadóban a kevésbé pozitív és hangsúlyosabban negatív érzelmek felé [22]. Továbbá a maszk gyengíti az érzelem által kiváltott motoros neuralis visszacsatolást, ami a fogadó fél érzelmi reakcióinak (például arckifejezés) megjelenését gátolja [23]. Ugyanakkor, mivel például a fájdalom legfontosabb nem verbális kommunikációs csatornája az arckifejezés, csökkentheti a fájdalom szubjektív érzetét, aminek diagnosztikai jelentősége is lehet $[24,25]$. Ezért fontos azoknak a specifikus nonverbális viselkedésformáknak az azonosítása, amelyek felhasználhatók az empatikus kommunikáció elősegítésére, amikor az érzelemkifejezésre szolgáló arcjegyek nem állnak rendelkezésre maszk viselése miatt. Számos kutatás született például az elmúlt években az átlátszó maszk viselésének előnyeiről a fogorvosi [14] és gyógyszerészeti [20] környezetben, valamint a gyermekgyógyászatban [26], illetve a hallássérültek [27] és a kognitív károsodást elszenvedők [28] kezelésében. Az átlátszó maszk használata a hagyományos sebészi maszkkal szemben elősegíti a bizalmi kapcsolat kialakítását és a szorongás csökkenését, mivel növekszik az egészségügyi dolgozók részéról mutatott, a páciensek által észlelt empatikus odafordulás, illetve a beszédértés $[18,29]$.

A maszkviselés hatására nemcsak az érzelmi állapotok olvasása és azonosítása nehezített, de nő a betegek bizonytalansága is arra vonatkozóan, hogy jól értelmezik-e a másik fél jelzéseit [25]. A nonverbális kommunikációnak ugyanis fontos szerepe van a kongruenciában is: az emberek inkább hisznek a testi jelzéseknek abban az esetben, ha a verbális és nem verbális kommunikáció között diszkrepanciát tapasztalnak. Az arc takarásán túl a jelenlegi járványügyi intézkedések a térközszabályozásra is hatással vannak, amely szintén fontos nonverbális kommunikációs eszköz. A túl nagy távolság érdektelenséget, személytelenséget jelenthet [3], ami további akadályként nehezedik a bizalmi kapcsolat építésére. Ráadásul ez a „kommunikációs stressz” - amellett, hogy mind a páciensek, mind az egészségügyi szakemberek pszichés jóllétére is negatívan hat - ronthatja az immunrendszer múködését is, akadályozva ezzel a betegséggel való megküzdést [10].

\section{A maszk és védóruházat okozta kommunikációs kihívások a kiemelt kockázati csoportok - gyermekek, idősek, kognitív károsodástól szenvedő és a hallássérült páciensek - esetében}

A COVID-19-járvány során az arcmaszkok viselése a legnagyobb kommunikációs kihívást az idősek és a kognitív károsodástól szenvedő páciensek (például Alzheimer-kór) [28], illetve a hallássérültek [30] számára jelenti, mivel az ő esetükben a vokális információk nagy része is elveszik a kommunikáció során, és a beszédértés romlása hozzájárul a szorongás növekedéséhez [31]. A vokális és verbális információk (például hangerő, hangszín, beszédtempó stb.) is számos üzenetet hordoznak érzelmi állapotainkról, és bár ez a csatorna a maszkviselés mellett is rendelkezésre áll, a vokális jelzések is torzulhatnak a hangképző szerveket takaró maszk miatt [12]. A beszédértést segítő vizuális információk (például a száj mozgása) is korlátozottá válnak. Az elmúlt évben és a pandémiás helyzet előtt is (például az ebola- és a H1Nljárvány tapasztalataiból) számos kutatás született arra vonatkozóan, hogy a beszédértést hogyan befolyásolja a maszk viselése [29, 31-37]. Az eredmények nem teljesen konzekvensek [38], mivel egyes kutatások szerint a maszk nem befolyásolja egészséges felnőtt személyeknél a beszédértést; azt azonban minden vizsgálat kimutatta, hogy a háttérzaj rontja a hallássérült és idős páciensek beszédértését [27, 39]. Kutatások szerint a túlartikuláció, a lassabb beszédtempó, az alacsonyabb hangfrekvencia és a hangosabb beszéd járulhat hozzá a könnyebb megértéshez, ám ebben a tekintetben is fontos, hogy a túl hangos kiabálás és az inkongruencia szorongáshoz is vezethet [18]. A maszk és a védőruházat miatt továbbá a betegek gyakran nem tudják megkülönböztetni az őket ellátó személyeket [1], illetve ez a nehézség gyakran az egészségügyi dolgozók hatékony munkavégzését is veszélyezteti [6]. A szakirodalom alapján tehát a felsorolt kognitív, pszichés, illetve fizikai nehezítő tényezők akadályozzák a bizalmi kapcsolat kialakítását és az empatikus orvos-beteg kommunikációt. A kommunikáció korlátai miatt különösen fontossá válik a transzparencia és a nyílt, tiszta verbális kommunikáció is: ha a páciens nem kap elegendő információt, magyarázatot az állapotával és az ellátással kapcsolatban, esetleg nem jól értelmezi azt, a hiányzó réseket saját tudása, beszúküult gondolkodása alapján fogja kitölteni [3].

Minden krízishelyzet sajátossága, hogy megnő a fogékonyság a negatív szuggesztiókra, ezért a türelmetlenség és a hirtelen mozdulatok ebben a helyzetben fokozott szorongást okozhatnak, és megnehezítik a kommunikációt - kiemelt tekintettel az idősekre és a gyermekekre [40]. Ugyanis a gyermekek és az idősek szuggesztibilitása magasabb [41], továbbá hajlamosabbak szorongást átélni negatív információk hatására [42]. Éppen ezért a gyermekgyógyászatban dolgozók körében is kiemelt 
szerepet kap a védőruházat okozta szorongás csökkentése $[26,43,44]$, melyre alkalmas például a figyelemelterelés mint kommunikációs eszköz, a gesztikuláció, a bólogatás, az élményszerü mesélés, a vizualizáció és a hipnoterápiás eszközök használata [43] vagy fénykép biztosítása az orvosról maszk nélkül. Swaminathan és Meera [45] szerint a gyermekek esetében különösen fontos a barátságos hangnem, az egyszerú mondatok használata gesztusok kíséretében, az ismétlés és a megfeleló szünetek, a vizuális eszközök, az emotikonok, rajzok alkalmazása annak érdekében, hogy elkerüljék a gyermek túlterhelését túl sok kérdéssel vagy információval.

\section{A maszk és védőruházat okozta kommunikációs kihívások az egészségügyi dolgozók körében}

Az elmúlt egy évben számos kutatás született azzal kapcsolatban is, hogy a védőruházat és a maszk viselése hogyan hat a dolgozók mentális egészségére, jóllétére és teljesítményére. Ezek a kutatások a maszkviselés legfon- tosabb hátrányos következményeiként nevezik meg a fizikai fáradtságot, a kényelmetlenséget és a sérüléseket, a teljesítmény csökkenését, illetve a kommunikációs nehézségeket [6-9, 44]. Nemcsak a betegekkel történő interakció, de a szakmai csapat egymás közötti kommunikációja is nehezített, hiszen egymást is nehezebb felismerni, meghallani és megérteni a védőöltözetben [44]. Az egészségügyi dolgozók pszichés megterhelését tovább fokozza, hogy miközben olyan ruházatot kell viselniük, amely akadályozza őket feladataik megszokott, korrekt ellátásában, gyakran ők maguk is félhetnek a fertőzéstől. Tehát ez az ambivalencia, miszerint a maszk és a védőruházat „szükséges, de mindent megnehezít”, komoly pszichológiai kihívást jelent a mentális egészség megőrzésében is. A védőruházat okozta problémák és negatív következmények hatására viszont az annak viselésével kapcsolatos compliance és adherencia csökkenhet, ami további feszültséget vált ki a dolgozók és a betegek között [9]. Érdekes adat azonban, hogy míg a COVID-19-járvány előtt, 2013-ban egy vizsgálatban $40 \%$ körüli adherenciát mértek a maszkviselésre vonatko-

1. táblázat |Az egyes kommunikációs csatornák használatára vonatkozó ajánlások és a hozzájuk kapcsolódó legfontosabb betegcsoportok

\begin{tabular}{|c|c|c|}
\hline Kommunikációs csatorna & Kommunikációs eszköz & A legfontosabb célcsoportok \\
\hline \multirow[t]{4}{*}{$\begin{array}{l}\text { Kommunikációs } \\
\text { környezet }\end{array}$} & A zavaró ingerek és zajok minimalizálása & $\begin{array}{l}\text { Hallássérültek, kognitív } \\
\text { károsodást elszenvedők és idősek }\end{array}$ \\
\hline & $\begin{array}{l}\text { Optimális láthatóság és elhelyezkedés biztosítása (szemből történő megközelítés, } \\
\text { szemmagasságban történő kommunikáció) }\end{array}$ & $\begin{array}{l}\text { Hallássérültek, kognitív } \\
\text { károsodást elszenvedők és idősek }\end{array}$ \\
\hline & Megfelelő idő biztosítása & $\begin{array}{l}\text { Szorongó páciensek, idősek, } \\
\text { gyermekek }\end{array}$ \\
\hline & A páciens egyéni szülkségleteihez igazított személyes belső környezet és kongruencia & Mindegyik csoport \\
\hline \multirow{8}{*}{$\begin{array}{l}\text { Verbális } \\
\text { kommunikáció }\end{array}$} & Bemutatkozás (lehetőleg név, beosztás, és az interakció céljának megjelölésével) & Mindegyik csoport \\
\hline & $\begin{array}{l}\text { Az érzelmek és nehézségek felismerése és normalizálása, az empátia kognitív szint- } \\
\text { jének kifejezése, továbbá a páciens biztosítása arról, hogy biztonságban van }\end{array}$ & Szorongó páciensek \\
\hline & A védőeszközök szükségességének alátámasztása & Szorongó páciensek \\
\hline & A páciens kérdezésre, illetve érzeteinek verbalizálására történő ösztönzése & Idősek, gyermekek \\
\hline & Folyamatos információátadás, ismétlés és visszacsatolás kérése & Idősek \\
\hline & $\begin{array}{l}\text { A nonverbális információk verbális megerősítése } \\
\text { (például „Visszamosolygok Önre”) }\end{array}$ & Mindegyik csoport \\
\hline & Vizualizáció, figyelemelterelés, mesélés, humor & Gyermekek \\
\hline & Zárt hurkú kommunikációs stratégia & Egészségügyi team \\
\hline \multirow[t]{5}{*}{$\begin{array}{l}\text { Nonverbális } \\
\text { kommunikáció }\end{array}$} & $\begin{array}{l}\text { Az alapvetó nonverbális eszközök tudatos felerősítése és a verbális információk } \\
\text { nonverbális megerósítése (például szemkontaktus, kézjelek használata, gesztiku- } \\
\text { láció) }\end{array}$ & $\begin{array}{l}\text { Hallássérültek, kognitív } \\
\text { károsodást elszenvedók és idősek }\end{array}$ \\
\hline & $\begin{array}{l}\text { Vizuális és írásos eszközök használata (például információs szórólapok, képek, } \\
\text { kártyák) }\end{array}$ & $\begin{array}{l}\text { Hallássérültek, kognitív } \\
\text { károsodást elszenvedók és } \\
\text { idősek, illetve gyermekek }\end{array}$ \\
\hline & $\begin{array}{l}\text { Vizuális információ biztosítása az egészségügyi dolgozóról maszk és védőruházat } \\
\text { nélkül és/vagy áttetsző maszk használata }\end{array}$ & Mindegyik csoport \\
\hline & $\begin{array}{l}\text { Feladatkörök megkülönböztetésére szolgáló eszközök, jelzések (például } \\
\text { ruházaton elhelyezett csíkok, sapkák) }\end{array}$ & Egészségügyi team \\
\hline & $\begin{array}{l}\text { Vokális információk, túlartikuláció, lassabb beszédtempó, alacsonyabb hang- } \\
\text { frekvencia és hangosabb (de nem túl hangos) beszéd, barátságos hangnem }\end{array}$ & $\begin{array}{l}\text { Hallássérültek, kognitív } \\
\text { károsodást elszenvedők és } \\
\text { idősek, illetve gyermekek }\end{array}$ \\
\hline
\end{tabular}


zóan intenzív osztályon dolgozó nővérek körében [46], addig egy 2020. áprilisi felmérés alapján ez az arány $80 \%$ körüli volt [47]. Összeségében tehát úgy túnik, hogy a pandémiás helyzet a védőeszközök hátrányos következményei ellenére megduplázta az azokra vonatkozó adherenciát az egészségügyi dolgozók körében. Ennek hátterében a pandémiás helyzet okozta fokozott félelem és szorongás, továbbá a megfelelően alkalmazott kríziskommunikáció is állhat.

\section{Ajánlások a maszk és védőruházat okozta akadályok kompenzálására}

A maszkviseléssel kapcsolatos kommunikációs akadályokkal és protokollokkal kapcsolatban számos ajánlás született az elmúlt években az aktuális COVID-19-, illetve a 2016. évi ebolajárvány idejéből [48]. Ezek többségében általános érvényú tanácsokat fogalmaznak meg, kiemelt tekintettel a kognitív károsodástól szenvedő, idős és hallássérült páciensekkel, illetve a gyermekekkel folyatott kommunikációra. A betegek szükségleteinek figyelembevétele mellett számos tanulmány felhívja a figyelmet és megoldást kínál a dolgozók közötti kommunikációs akadályok leküzdésére is. A fentiek alapján a nemzetközi irodalom ajánlásai összesen három kommunikációs csatorna köré szerveződnek: a verbális és a nonverbális kommunikációs csatorna mellett kiemelt figyelmet kap a szuggesztív kommunikációs szempontból is meghatározó kommunikációs környezet (1. táblázat).

\section{A megfelelő külső és belső kommunikációs környezet}

A legtöbb ajánlás szerint a hatékony kommunikáció fenntartása érdekében a maszk és a védôruházat viselése során a legfontosabb szempont a megfelelő kommunikációs környezet kialakítása [12]. A megfelelő kommunikációs környezet magában foglalja a (1) zavaró ingerek és zajok minimalizálását a páciens megfelelő figyelmi fókuszának és beszédértésének érdekében, (2) az optimális láthatóság (lehetóleg szemből történő megközelítés és szemmagasságban történő kommunikáció, továbbá megfelelő fényviszonyok az amúgy is takarásban lévó arckifejezések könnyebb azonosítása érdekében) [49] és a ráfordított idő biztosítását, továbbá összességében (3) olyan környezet kialakítását, melyben a páciens érzései és gondolatai is teret kapnak. A kommunikációs szempontból megfelelő vizuális és auditoros környezeti ingerek előkészítése mellett ugyanis ideális esetben az orvos-beteg konzultációt megelőzi egy belső, személyes felkészülési és önvizsgálati fázis, melynek során az egészségügyi dolgozó tudatosítja (1) a helyzet adta specifikus szempontokat, például annak aszimmetriáját (szakértő-laikus, egészséges-beteg, függő-független, kognitíven ép-sérült; idős-fiatal), továbbá (2) a saját hipotéziseit, gondolatait, gesztusainak és testbeszédének jellegzetességeit annak érdekében, hogy képes legyen kongruensen összehangolni nonverbális jelzéseit a kimondott üzenetekkel [40].

\section{Nonverbális kommunikáció és a személytelenség enyhítése}

A nemzetközi ajánlások szerint a maszk és a védőruházat viselése során minden esetben az egyik legalapvetőbb feladat (1) a nonverbális kommunikációs eszközök tudatos felerősítése, úgymint a szemkontaktus fenntartása, az irányok és a legfontosabb információk kézjelekkel történő jelzése (például a hüvelykujj felfelé vagy lefelé tartása, mellyel tisztázható, hogy az információt megfelelôen megértették-e a páciensek; Nightingale-módszer [50], a bólogatás és a hangsúlyosabb gesztikuláció, a testbeszéd, a megfelelő vokális jegyek és távolság. Fontos továbbá (2) a nonverbális információk verbális megerősítése (például „Visszamosolygok Önre”) az érzelmek egyértelmü kifejezésének és a páciensek megértésének támogatására. A beteg igényeihez alkalmazkodó, megfelelő ritmusú szemkontaktus az aktív figyelmet, odafordulást és elérhetőséget fejezi ki [3]. Ezeken túlmenően (3) a vizuális és írásos eszközök használata is hatékonynak bizonyul, mivel az írott tartalom kimondott információval történő egyidejű biztosítása redundanciát teremt, ezáltal csökkentve azt az információmennyiséget, amelyet a páciensnek a munkamemóriájában kell tárolnia [18]. A vizuálisan is hozzáférhető kommunikációs eszközök - például a kártyák, jegyzettömbök, információs szórólapok, videók vagy speciális alkalmazások használata - tehát hasznos módszerek lehetnek az információk bemutatására vagy átismétlésére, a betegek kognitív és kommunikációs készségeihez igazítva. Ezek az eszközök nemcsak a betegek, de az egészségügyi dolgozók közötti kommunikációt is elősegíthetik.

A személytelenség, az elidegenedettség kompenzálására is számos jó gyakorlat létezik a nemzetközi irodalomban. Az áttetsző maszk használatának előnyei mellett a legtöbb kutatás és ajánlás azt hangsúlyozza, hogy amennyiben lehetséges, a dolgozók biztosítsanak vizuális információt (név és kép) önmagukról, maszk és védőruházat nélkül. A személyesség és a hatékony munkavégzés elősegítése érdekében megoszthatnak önmagukról vagy a szerepükről egy személyes vagy más jellegzetes információt a könnyebb beazonosíthatóság érdekében. Duan és mtsai [6] például különböző színú sapkákat használtak az egyes feladatkörök megkülönböztetésére, míg Shurlock és mtsai [50] színes csíkokkal jelölték az intenzív osztályon dolgozó munkatársakat a beosztásuk és feladataik alapján. A helyzet megoldására már itthon is vannak bevált gyakorlatok: például az ellátók felragasztják nevüket és fényképüket a védőruhára, vagy egy plexiüveg mögül megmutatják arcukat a pácienseknek. Ezek a gesztusok nagyon fontos szerepet játszhatnak a bizalmi kapcsolat kiépítésében. 


\section{A verbális kommunikáció}

Végül, a legkézenfekvőbb verbális kommunikációs eszközök is elősegíthetik az egészségügyi dolgozók és a betegek együttmúködését. Ennek is kiemelt szerep jut, hiszen a dolgozók beszámolója szerint $80 \%$-ban a beszéddel „dolgoznak” [18]. A verbális kommunikáció elemeire vonatkozóan a szakirodalmi ajánlások összefoglalóan a következők: (1) A bemutatkozás szerepe a maszkviseléssel még nagyobb hangsúlyt kap, ugyanis ha elmarad a bemutatkozás, annak negatív szuggesztiós tartalma van [13], melyet a maszkviselés okozta személytelenség fokozhat, növelve a beteg szorongását. Fontos továbbá (2) felismerni, hogy a maszk viselése mindenki számára kihívást jelent, és normalizálni, ha emiatt feszültséget érez a beteg, illetve biztosítani a beteget arról, hogy biztonságban van; (3) igazolni a védőeszköz szükségességét a fertőzések megelőzésére; (4) ösztönözni az arcmaszkot viselő beteget a kérdezésre és arra, hogy érzéseit, érzeteit, például fájdalmait verbálisan kommunikálja; (5) végül folyamatos tájékoztatás és információátadás mellett viszszacsatolást kérni arra vonatkozóan, hogy a páciens jól hallotta és megértette a neki szánt információkat. Idős, rosszul halló betegek esetében ez kiemelten fontos, mivel gyakran a szorongás és a szégyenérzet miatt nem mernek visszakérdezni [31].

A verbális kommunikációnak fontos szerepe van a kognitív empátia kifejezésében is. Az ellátó - miután felismerte és megértette a beteg aktuális helyzetre vonatkozó nézőpontját, vélekedéseit és érzéseit - visszajelzést adhat ezekről a verbális kommunikáció szintjén, így szabályozva a páciens szorongását. Az egészségügyi dolgozók kognitív empátiás képessége fejleszthető pszichoedukációval, melynek során bővíthetik ismereteiket a páciensek és a hozzátartozók megváltozott mentális müködéséről.

A speciális verbális kommunikációs eszközök használata nemcsak a betegek, de a dolgozók egymás közötti kommunikációjában is releváns. A zárt hurkú kommunikációs stratégia, melynek során a fogadó fél minden alkalommal szó szerint megismétli a hallott üzenetet, például hatékonyan alkalmazható annak érdekében, hogy az egészségügyi dolgozók egymás között meggyőződjenek arról, biztosan jól értették-e az utasításokat. A kommunikációs stratégia alkalmazásakor azonban fontos elmagyarázni a pácienseknek ennek okát és szerepét, ugyanis előfordulhat, hogy másként értelmezik, és azt gondolják, hogy az egészségügyi személyzet nem érti meg egymást $[19,50]$. Az ellátók közötti verbális és nonverbális kommunikáció fejlesztése azért is fontos, mert az ellátás során minden, ami a beteg környezetében történik, szuggesztív hatással bír (1. táblázat).

Az egészségügyi ellátásra szoruló betegek az ellátást követően általában arra emlékeznek a leginkább, hogy hogyan kommunikáltak és hogyan bántak velük. Az orvos-beteg kapcsolat és kommunikáció olyan összetett jelenség, amelynek aspektusait számos kutatás vizsgálta az egészségügy különböző területein. A COVID-19-járvány - a maszkviselés és a védőruha-használat által azonban számos olyan nehézséget hozott magával az orvos-beteg kapcsolat vonatkozásában, amely megfelelő tudatosítás és kezelés nélkül hosszú távon ronthatja a kommunikáció színvonalát, és elősegítheti a deperszonalizáció és az érzelmi távolságtartás megjelenését az orvos-beteg interakciókban. A kommunikációban megjelenő fizikai és lélektani akadály az eddig ismert és alkalmazott kommunikációs protokollok rendszerezését és bővítését kívánja meg.

Az elmúlt évben a járvány hosszú távon változtatta meg az egészségügyi szakemberek személyes konzultációinak hagyományos nézetét és eszközeit, és gyors alkalmazkodást tett szükségessé az egészségügyi kommunikáció területén. Előtérbe kerültek az online kommunikációs csatornák, amelyek lehetőséget biztosítottak az egészségügyi dolgozók közötti generációs különbségek áthidalására is [51]. A járványhelyzet elmúlt egy évében továbbá számos olyan hazai és nemzetközi intervenció is született, mely arra utal, hogy az egészségügyi dolgozók is érzik a verbális és nonverbális kommunikáció kihívásait, és képesek adaptálódni ehhez a krízishez. A védőruházatra felragasztott képek és megkülönböztető jelzések, a speciális kommunikációs eszközök (például zárt hurkú kommunikációs stratégia, kézjelek használata) nemzetközileg elismert és a kommunikációt segítő, hatékonyan múködő módszerek. Ugyanakkor a COVID-19 pszichológiai értelemben új, sokszor megjósolhatatlan és kontrollálhatatlan jelenség: a folyamatos készenléti állapot és bizonytalanság, szorongás és félelem pszichésen rendkívül kimerítő mindenki számára. Ez az elhúzódó, fizikai és lelki értelemben vett krízishelyzet komolyan veszélyezteti az egészségügyi dolgozók mentális egészségét, ezért különösen fontos, hogy rendelkezzenek olyan eszközökkel, amelyek védelmet jelentenek a kiégéssel szemben. Fontos ezért hangsúlyozni azt is, hogy az elmúlt évben nemzetközileg és hazánkban is megjelentek olyan kezdeményezések, melyek célja a frontvonalban lévő egészségügyi dolgozók pszichés támogatása (például Bálint-csoportok). Amellett, hogy ezeknek a kezdeményezéseknek bizonyítottan pozitív hatásuk van a mentális jóllétre, úgy tűnik, hogy a kommunikációs kihívásokkal történő megküzdést is hatékonyan elősegítik [52]. Nem lehet elégszer hangsúlyozni, hogy az ellátó és a páciens között létrejövő interperszonális kapcsolat önmagában is gyógyító erôvel bír [53]. Az empatikus kommunikáció és a bizalomra, kölcsönösségre épülő kapcsolatok „visszahatnak” az ellátóra, növelik a hatékonyságérzést, az elégedettséget, és hozzásegítenek a mindennapi munkában megélhető sikerélményekhez.

Anyagi támogatás: A közlemény megírása, illetve a kapcsolódó kutatómunka anyagi támogatásban nem részesült. 
Szerzôi munkamegosztás: G. B., K. P.: A szakirodalom áttekintése és elemzése. G. B., K. P., B. B. és F. Zs.: A kézirat elkészítése, megszövegezése. A cikk végleges változatát valamennyi szerző elolvasta és jóváhagyta.

Érdekeltségek: A szerzőknek nincsenek érdekeltségeik.

\section{Irodalom}

[1] Duckett K. Behind the mask: new challenges to gaining patient trust. Home Healthcare Now 2020; 38: 327-330.

[2] Youngson R. TIME to CARE: How to love your patients and your job. [Együttérző gyógyítás: Szemléletváltás az orvoslásban.] HVG Kiadó, Budapest, 2018. [Hungarian]

[3] Pilling J. Medical communication in practice. [Orvosi kommunikáció a gyakorlatban.] Medicina Könyvkiadó, Budapest, 2018. [Hungarian]

[4] McCarthy B, O'Donovan M, Trace A. A new therapeutic communication model "TAGEET" to help nurses engage therapeutically with patients suspected of or confirmed with COVID-19. J Clin Nurs. 2021; 30: 1184-1191.

[5] Robblee J, Buse DC, Singh RB, et al. Ten eleven things not to say to healthcare professionals during the coronavirus disease 2019 pandemic. Headache 2020; 60: 1837-1845.

[6] Duan X, Sun H, He Y, et al. Personal protective equipment in COVID-19: impacts on health performance, work-related injuries and measures for prevention. J Occup Environ Med. 2021; 63: 221-225.

[7] Benítez CY, Güemes A, Aranda J, et al. Impact of personal protective equipment on surgical performance during the COVID-19 pandemic. World J Surg. 2020; 44: 2842-2847.

[8] Swaminathan R, Mukundadura BP, Prasad S. Impact of enhanced personal protective equipment on the physical and mental well-being of healthcare workers during COVID-19. Postgrad Med J. 2020; 139150

[9] Hoernke K, Djellouli N, Andrews L, et al. Frontline healthcare workers' experiences with personal protective equipment during the COVID-19 pandemic in the UK: a rapid qualitative appraisal. BMJ Open 2021; 11: e046199.

[10] Campagne DM. The problem with communication stress from face masks. J Affect Disord Rep. 2021; 3: 100069.

[11] Neilson $S$. The surgical mask is a bad fit for risk reduction. CMAJ 2016; 188: 606-607.

[12] Marler H, Ditton A. "I'm smiling back at you": exploring the impact of mask wearing on communication in healthcare. Int J Lang Commun Disord. 2021; 56: 205-214.

[13] Varga K, Diószeghy Cs. Cash in for refrigeration, or the role of suggestions in everyday medical practice. [Hütésbefizetés avagy a szuggesztiók szerepe a mindennapi orvosi gyakorlatban.] Pólya Kiadó, Budapest, 2013. [Hungarian]

[14] Emanuel R, Corcoran R, Cass H. A study of special care dental patient preference toward choice of mask and visor use by dental clinicians. Spec Care Dent. 2017; 37: 164-167.

[15] Wong CKM, Yip BHK, Mercer S, et al. Effect of facemasks on empathy and relational continuity: a randomised controlled trial in primary care. BMC Fam Pract. 2013; 14: 1-7.

[16] Argyle M. (ed.) Social encounters: readings in social interaction. Aldine Publishing Co., Chicago, IL, 1973.

[17] Mehrabian A. Silent messages: implicit communication of emotions and attitudes. Wadsworth Publishing Company, Belmont, CA, 1971 .

[18] Knollman-Porter K, Burshnic VL. Optimizing effective communication while wearing a mask during the COVID-19 pandemic. J Gerontol Nurs. 2020; 46: 7-11.

[19] Schlosser M, Adao K, Derkyi A, et al. Communication challenges in high-containment clinical environments. Am J Nurs. 2021; 121: $40-45$
[20] Kishimoto K, Hasaka A, Yamaura K, et al. Whether visual information loss of expression by community pharmacist masks to effect a change in feeling of trust among help-seeker? Yakugaku Zasshi: J-Stage 2016; 136: 1401-1413.

[21] Grundmann F, Epstude K, Scheibe S. Face masks reduce emotion-recognition accuracy and perceived closeness. PLoS ONE 2021 ; 16(4): e0249792.

[22] Fischer AH, Gillebaart M, Rotteveel M, et al. Veiled emotions: the effect of covered faces on emotion perception and attitudes. Soc Psychol Pers Sci. 2012; 3: 266-273.

[23] Mehta UM, Venkatasubramanian G, Chandra PS. The "mind" behind the "mask": assessing mental states and creating therapeutic alliance amidst COVID-19. Schizophr Res. 2020; 222: 503-504.

[24] Coles NA, Larsen JT, Lench HC. A meta-analysis of the facial feedback literature: effects of facial feedback on emotional experience are small and variable. Psychol Bull. 2019; 145: 610.

[25] Vonyik G, Farkas M, Turner A, et al. The effect of mask wearing on the doctor-patient relationship. [A maszkviselés hatása az orvos-beteg kapcsolatra.] Hyperton Nephrol 2020; 24: 229-233. [Hungarian]

[26] Shack AR, Arkush L, Reingold S, et al. Masked paediatricians during the COVID-19 pandemic and communication with children. J Paediatr Child Health 2020; 56: 1475-1476.

[27] Naylor G, Burke LA, Holman JA. Covid-19 lockdown affects hearing disability and handicap in diverse ways: a rapid online survey study. Ear Hear 2020; 41: 1442-1449.

[28] Gil R, Arroyo-Anlló EM. Alzheimer's disease and face masks in times of COVID-19. J Alzheimer's Dis. 2021; 79(1): 9-14.

[29] Atcherson SR, Mendel LL, Baltimore WJ, et al. The effect of conventional and transparent surgical masks on speech understanding in individuals with and without hearing loss. J Am Acad Audiol. 2017; 28: 58-67.

[30] Trecca EM, Gelardi M, Cassano M. COVID-19 and hearing difficulties. Am J Otolaryngol. 2020; 41: 102496.

[31] Chodosh J, Weinstein BE, Blustein J. Face masks can be devastating for people with hearing loss. BMJ 2020; 370: m2683

[32] Mendel LL, Gardino JA, Atcherson SR. Speech understanding using surgical masks: a problem in health care? J Am Acad Audiol. 2008; 19: 686-695.

[33] Radonovich Jr, LJ, Yanke R, Cheng J, et al. Diminished speech intelligibility associated with certain types of respirators worn by healthcare workers. J Occup and Environ Hyg. 2009; 7: 63-70.

[34] Wittum KJ, Feth LL, Hoglund EM. The effects of surgical masks on speech perception in noise. J Acoust Soc Am. 2013; 133: 3391-3391.

[35] Hines SE, Oliver MS, Gucer P. Self-reported impact of respirator use on health care worker ability to perform patient care. Am J Infect Control 2020; 48: 1556-1558.

[36] Bandaru SV, Augustine AM, Lepcha A, et al. The effects of N95 mask and face shield on speech perception among healthcare workers in the coronavirus disease 2019 pandemic scenario. J Laryngol Otol. 2020; 134: 895-898.

[37] McKee M, Moran C, Zazove P. Overcoming additional barriers to care for deaf and hard of hearing patients during COVID-19. JAMA Otolaryngol Head Neck Surg. 2020; 146: 781-782.

[38] White SJ, Barello S, di San Marco EC, et al. Critical observations on and suggested ways forward for healthcare communication during COVID-19: pEACH position paper. Patient Educ Couns. 2021; 104: 217-222.

[39] Muzzi E, Chermaz C, Castro V, et al. Short report on the effects of SARS-CoV-2 face protective equipment on verbal communication. Eur Arch Otorhinolaryngol. 2021 Jan 3. Doi: 10.1007/ s00405-020-06535-1. [Epub ahead of print]

[40] Schlögl M, Jones CA. Maintaining our humanity through the mask: mindful communication during COVID-19. J Am Geriatr Soc. 2020; 68: E12. 
[41] Page RA, Green JP. An update on age, hypnotic suggestibility, and gender: a brief report. Am J Clin Hypn. 2007; 49: 283-287.

[42] Moutsiana C, Garrett N, Clarke RC, et al. Human development of the ability to learn from bad news. Proc Natl Acad Sci USA 2013; 110: 16396-16401.

[43] Crowe AML. Communication skills with children in paediatric anaesthesia: challenges while wearing a face mask. BMJ Paediatr Open $2020 ; 4: 1$.

[44] Hampton T, Sharma S, Dunham M, et al. We still can't hear: staff perceptions of personal protective equipment impact on speech and communication in the operating theater during paediatric airway surgery. Paediatr Anaesth. 2021; 31: 494-496.

[45] Swaminathan D, Meera SS. Masks mask communication - communicating with children in health care settings. Indian J Pediatr. 2021; 88: 283-284.

[46] Nichol K, McGeer A, Bigelow P, et al. Behind the mask: determinants of nurse's adherence to facial protective equipment. Am J Infect Control 2013; 41: 8-13.

[47] Neuwirth MM, Mattner F, Otchwemah R. Adherence to personal protective equipment use among healthcare workers caring for confirmed COVID-19 and alleged non-COVID-19 patients. Antimicrob Resist Infect Control 2020; 9: 1-5.

[48] Brown-Johnson C, Vilendrer S, Heffernan MB, et al. PPE portraits - a way to humanize personal protective equipment. J. Gen Intern Med. 2020; 35: 2240-2242.
[49] Kilgore B, Harriger C, Gaeta L, et al. Unmasking misunderstandings: strategies for better communication with patients. Nursing 2021; 51: 56-59.

[50] Shurlock J, Rudd J, Jeanes A, et al. Communication in the intensive care unit during COVID-19: early experience with the Nightingale Communication Method. Int J Qual Health Care 2021; 33: mzaal62.

[51] Julka-Anderson N. How COVID-19 is testing and evolving our communication skills. J Med Imaging Radiat Sci. 2020; 51: S11S13.

[52] Yang C, Zhou B, Wang J, et al. The effect of a short-term Balint group on the communication ability and self-efficacy of pre-examination and triage nurses during COVID-19. J Clin Nurs. 2021; 30: 93-100.

[53] Bálint M. The doctor, his patient, and the illness. [Az orvos, a beteg és a betegség.] Animula Kiadó, Budapest, 2004. [Hungarian]

\section{„Bis fiet gratum quod opus est si ultro offeras." (Szükségben kétszeresen kedves az önként felajánlott segítség.)}

A cikk a Creative Commons Attribution 4.0 International License (https://creativecommons.org/licenses/by/4.0/) feltételei szerint publikált Open Access közlemény, melynek szellemében a cikk bármilyen médiumban szabadon felhasználható, megosztható és újraközölhető, feltéve, hogy az eredeti szerző és a közlés helye, illetve a CC License linkje és az esetlegesen végrehajtott módosítások feltüntetésre kerülnek. (SID_1) 